\title{
Comparative Analysis of the China-South Korea and China-Australian Bilateral Trades Commodity Structure
}

\author{
Pei-Zhi Wang ${ }^{1, a}$, Jun-Feng Ju ${ }^{2, b,{ }^{*}}$ \\ ${ }^{1,2}$ Shandong university of Finance and Economics, shun geng Road 40, Jinan City, Shandong \\ Province, China \\ awpzmail@126.com, bjjfjyc@qq.com \\ ${ }^{*}$ Corresponding author
}

Keywords: China-South Korea trade, China-Australian trade, Trade commodity structure.

\begin{abstract}
In recent years, the China-South Korea and China-Australian bilateral trades are growing steadily. However, they also confront challenges of trade competitions. Based on the study of the development and current situation of China-South Korea and China-Australian bilateral trades, this paper analyzes the commodity structures. The results show that, the growing bilateral trades, import and export commodity structure constantly adjusting, and then on the prospect of China-South Korea, Sino-Australian bilateral trades further development, and have positive significance to make correct foreign trade policy.
\end{abstract}

\section{Introduction}

Under the background of economic globalization, trade liberalization and capital globalization have promoted the development of regional economic integration. Right now China is in a new stage of reform and opening up, economic development of the country, to carry out foreign trade, the establishment of new institutional mechanisms, improve the international competitiveness of a country and comprehensive national strength has become the important issue in the China urgently awaits to be solved. In recent years, China has vigorously developed foreign trade, in particular, focusing on trade exchanges and cooperation with neighboring countries. Through respectively, to study the development and the current situation of China and South Korea, the bilateral trade, and further analysis of China and South Korea, Sino Australian bilateral trade commodity structure and of being established and South Korea free trade area, Australia free trade area construction has positive significance; to forecast of China's foreign trade hair trend, make correct foreign trade policy has great significance.

\section{Development and Current Status of the China-South Korea and China-Australian Bilateral trades}

\section{Development and Current Status of the China-South Korea}

Since the establishment of diplomatic relations between China and South Korea, the bilateral economic and trade relations have been developing rapidly, and the trade volume of China and South Korea rose from $\$ 5.03$ billion in 1992 to $\$ 274.2$ billion in 2013, and increased nearly 50 times since the establishment of diplomatic relations. It is estimated that by 2015, China and South Korea trade volume will exceed $\$ 300$ billion. According to relevant information, in 2012 the trade volume of China and South Korea is $\$ 256.3$ billion, an increase of $4.4 \%$, in 2013 , bilateral trade volume is $\$ 274.248$ billion, an increase of $7 \%$.Korea is my third largest trading partner and third largest export target country and the second largest source of imports. 2012 Chinese Minister of Commerce Chen Deming and South Korean Foreign Minister Park Tae-ho in Beijing issued a joint statement announcing the official launch of China-ROK FTA negotiations and further deepen bilateral strategic cooperative partnership. On 1 June 2015, China and South Korea Free Trade Agreement (FTA) formally signed, which for China and South Korea bilateral trade exchanges has landmark significance. This is the highest degree of freedom of the 
Chinese history signed, the most widely involved in the field of free trade agreement. The following table analyzes the changes in the form of China-South Korea trade volume in 11 years.

Tab. 1 2001-2011 China-South Korea trade volume change (Unit: 100 million USD)

\begin{tabular}{|c|c|c|}
\hline Year & Chinese exports to South Korea & Chinese imports from South Korea \\
\hline 2001 & $125.19(4.7 \%)$ & $233.77(9.6 \%)$ \\
\hline 2002 & $155.35(4.77 \%)$ & $285.68(9.68 \%)$ \\
\hline 2003 & $200.99(4.59 \%)$ & $431.28(10.45 \%)$ \\
\hline 2004 & $278.12(4.69 \%)$ & $622.34(11.09 \%)$ \\
\hline 2005 & $351.08(4.61 \%)$ & $768.20(11.64 \%)$ \\
\hline 2006 & $445.22(4.59 \%)$ & $897.24(11.34 \%)$ \\
\hline 2007 & $564.32(4.63 \%)$ & $1037.52(10.85 \%)$ \\
\hline 2008 & $739.32(5.17 \%)$ & $1121.38(9.9 \%)$ \\
\hline 2009 & $536.80(4.47 \%)$ & $1025.52(10.20 \%)$ \\
\hline 2010 & $687.66(4.36 \%)$ & $1383.39(9.91 \%)$ \\
\hline 2011 & $829.20(4.37 \%)$ & $1627.17(9.33 \%)$ \\
\hline
\end{tabular}

First of all, it can be seen from the table, in 2001, Chinese exports to South Korea \$ 12.591 billion, accounting for $4.7 \%$ of China's total exports that year scale. Chinese imports from South Korea amounted to $\$ 23.377$ billion, accounting for $9.6 \%$ share of China's total imports that year. Since then, the scale of China's exports to South Korea continued to expand. Affected by the 2008 financial crisis, the amount of imports and exports in 2009 decreased significantly. Displayed in the table, with the exception of 2009, the rest of the year remained 20\% -30\% growth rate. China's imports from South Korea is also expanding the scale, but the larger import growth volatility, in 2003, annual growth rate of 50.97\%. Second, China's exports to South Korea's change in the proportion of China's total exports is unlikely, Chinese imports accounted for the change in the proportion of China's total imports from South Korea more.

\section{Development and Current Status of the China-Australian}

China-Australian bilateral trade has a long history. At the end of the 19th century, Australia has exports to China iron ore; after the founding of new China in 1949, although at that time between Australia and China did not establish diplomatic relations, but there has been private trade; in 1972 the two countries established diplomatic ties, bilateral trade scale is relatively small, when the volume of trade only $\$ 72$ million; in the 21 st century, with the increasing openness of the Chinese market, the rapid development of China's economy, Australia provides a broad market, closer links between China and Australia, causing more attention from all over the world. For now, the bilateral trade in both China and Australia is competitive and there are also complementary. Because there are many similarities between the two countries in the economic development, this strengthens the China- Australian bilateral trade and mutual competition, also because of different economic development patterns of these two countries, making bilateral trade between the two countries can complement each other. Between China and Australia in the past 20 years, economic relations has been the rapid growth. So far, China has maintained Australia's big five first: the first major trading partner, the largest export market, the largest source of imports, largest export destination for trade in services, but also the largest source of tourism revenue. According to the relevant statistics, the trade volume between China and Australia each year showed a jump growth. From 2000 to 2010, trade between China and Australia grew from $\$ 8.45$ billion to $\$ 88.326$ billion, decade trade increased nine-fold. the trade volume between China and Australia grew by 9 times. Meanwhile, China's trade deficit in Australia continues to zoom. China exports to Australia reached $\$ 307$ billion, increased by 4 times, China imports from Australia reached $\$ 603$ billion, increased by 10 times, and China from Australia deficit reached the 33.885 billion US dollars, increased 21.25 times. From 2013, the China-Australian bilateral trade volume reached 141.76 billion Australian dollars, an increase of $20.7 \%$. The following analysis in tabular form in Australia trade changes.

Following table analysis available, under the joint efforts of the two governments and promotion of bilateral trade, bilateral trade continued to grow and sustained development. In 2009, bilateral trade volume is 46 times the amount of 1980, which fully shows that China and Australia have become an 
increasingly important trading partner. From the data, the proportion of Sino Australian trade in total Chinese total trade declined year by year, while Australia trade accounted for the proportion of total Australian trade increased

Tab. 2 Australia trade changes (Unit: 100 million USD)

\begin{tabular}{|c|c|c|c|}
\hline Year & $\begin{array}{c}\text { The bilateral } \\
\text { trade volume }\end{array}$ & $\begin{array}{c}\text { The proportion of China's } \\
\text { total imports and exports }\end{array}$ & $\begin{array}{c}\text { Australia accounts for the proportion of } \\
\text { the total import and export }\end{array}$ \\
\hline 1980 & 12.87 & $6.4 \%$ & $2.9 \%$ \\
\hline 1990 & 18.09 & $3.4 \%$ & $2.2 \%$ \\
\hline 1995 & 42.11 & $3.2 \%$ & $3.7 \%$ \\
\hline 2000 & 84.53 & $1.8 \%$ & $6.2 \%$ \\
\hline 2009 & 600.84 & $2.72 \%$ & $18.8 \%$ \\
\hline
\end{tabular}

\section{Analysis of the China-South Korea and China-Australian Bilateral Trades Commodity Structure}

\section{Analysis of the China-South Korea bilateral trade commodity structure}

China and South Korea at the same time, the growing volume of trade, import and export commodity structure has also been adjusted.

Audio-visual equipment and the electrical and mechanical parts, textile raw materials and products, mineral products, base metals and products, chemical products, plants and their products is China's exports to South Korea's six major categories of merchandise, accounting for $80 \%$ of total exports to South Korea. China exports to South Korea, the amount of steel exports continued to grow, iron and steel trade deficit amount increased from $\$ 200$ million in 2005 to $\$ 1.95$ billion, an increase of nearly 10 times. Reasons for the phenomenon, on the one hand is the gap between the iron and steel industry of Sino Korea gradually reduced, on the other hand, a lot of iron and steel enterprises in South Korea to China to invest and set up factories, which have increased the demand for steel in South Korea. Among them, the export growth of China to South Korea is mainly copper and its products and motor vehicles and its zero attachment, respectively, an increase of $74.7 \%$ and $142.9 \%$.

In January-July 2012, for example, the following table lists the major commodities of our country's exports to South Korea. China's exports to South Korea's main commodity is high-tech products, steel, agricultural and textile products, in which electromechanical products, high-tech products, the proportion of significantly larger. Mechanical and electrical products exports amounted to $\$ 28.98$ billion dollars, exports of high-tech products amounted to $\$ 17.98$ billion. The following table is used to analyze the situation.

Tab. 3 China's exports to South Korea's main commodity

\begin{tabular}{|c|c|c|}
\hline Product Name & Dollar value (US\$ billion ) & On year-on-year basis (\%) \\
\hline $\begin{array}{c}\text { Mechanical and Electrical } \\
\text { Products }\end{array}$ & 289.8 & 18.2 \\
\hline $\begin{array}{c}\text { Where: electrical and electronic } \\
\text { products }\end{array}$ & 167.1 & 32.5 \\
\hline High-tech products & 179.8 & 27.5 \\
\hline Steel & 46.8 & -14.1 \\
\hline Produce & 22.5 & -7.3 \\
\hline $\begin{array}{c}\text { Textile yarn, fabrics and related } \\
\text { products }\end{array}$ & 14.5 & -20.2 \\
\hline
\end{tabular}

According to relevant statistics, audio-visual equipment and the electrical and mechanical parts, rubber and plastic products, textile raw materials and products, mineral products, base metals and products, chemicals and products are exported to South Korea to China's six kinds of main commodities accounted for $79.4 \%$ of 2001 South Korean exports to China the amount of goods .Since 2003, optical and medical 
instruments have replaced the raw materials and products of textile, and have become the second major commodities imported from South Korea, and chemical and products are also increased by third kinds of commodities. Compared with 2001, in 2009, China imported from South Korea six categories of goods increased by almost 5 times, from South Korea's imports of $92.2 \%$, an increase of 13.5 percentage points over the same period.

According to China from the point of view of the structure of the South Korean imports of products, the product from raw materials to finished products, from low added value to high value added direction lifting, economic and trade relations between the two countries has entered new stage.

analysis of the China-Australian bilateral trade commodity structure

The reason why the China- Australian economic and trade relations can develop steadily and rapidly, the reason is that the two countries trade has a strong complementary. On the one hand, Australia has abundant natural resources, minerals, energy products, agricultural products can be long-term supply the Chinese market; on the other hand, China has abundant labor resources and broad market, to Australia to provide light industry, textile, electrical and mechanical and other labor-intensive products, can also provide such satellite launch this high-tech services. Therefore, the two countries trade complementary is very strong, there is a great potential for cooperation.

The study found that China's exports to Australia are mainly manufactured goods, in which three kinds of products of mechanical and electrical products, textiles and furniture products accounted for six of China's exports to Australia. China has rich and cheap labor resources, which makes the price of China's labor-intensive products is much lower than the Australian production of similar products; in the manufacturing industry chain, with the improvement of the status of China, some of the high value-added export products are also increasing, such as China's motor, electrical and nuclear reactors products. Australia imports from China's main commodity is mechanical and electrical products, textiles and base metals and products. In addition, furniture, toys, miscellaneous products, plastics, rubber, transportation equipment, and other major categories of imports for Australia's major commodities.

China has abundant labor force, China's exports to Australia is mainly labor-intensive products, while Australia has vast resources, Australian exports to China's products are mainly agricultural products and minerals resource type. In the 2011 Australian import and export trade structure, China's exports to Australia is mainly textile and garment, electrical and mechanical products, two types of products accounted for $56 \%$ of Chinese exports to Australia and the total value of the products. Australia exports to China's mineral resources based products and its associated metal products accounted for 76\%.Australia's mineral exports to China has been the main product, exports from January to March 2013 was \$ 15.58 billion, up 19.5\%, accounting for 75.0 percent of China's total exports to Australia. The relevant data shows that, precious metal and product is Australian exports to China the second largest category of merchandise, as Australia's 9.1\% of China's total exports accounted for, textiles and raw materials is the Australian exports to China the third largest category of merchandise, as Australia's 3.2\% of China's total exports accounted for. In addition, base metals and products become Australia's exports to China's fourth major products, accounting for $2.8 \%$ of its total exports to China.

\section{Conclusion}

Through the development and current situation of South Korea, Australia bilateral trade knowledge, the analysis of China-South Korea and China-Australian trade commodity structure, the following conclusions can be made for their bilateral trade:

First, China and South Korea in terms of productivity and production relations, economic base and superstructure with strong differences and complementary, this is China and South Korea reached trade cooperation foothold, but also to achieve long-term cooperation to achieve the necessary foundation for mutual benefit and win-win. Growing trade between the two countries of China and South Korea, structure of import and export commodities have been adjusted, with both countries' industrial structure adjustment, increase the amount of trade between the two countries, product structure also to diversified development, the rational propulsion. From the point of view of the product structure of exports to China and South Korea, South Korea is China's export products with high content of science and technology, South Korea on China's export commodities in a certain period of time will still to mechanical and 
electrical products, audio and video equipment and accessories, and chemical products mainly; and Chinese exports to South Korea mainly to mechanical and electrical products, textile raw materials and products. Today in the increasing development of science and technology innovation and technology trade in trade cooperation plays a more and more important role. China also strengthened the development of our country science and technology innovation enterprise, strengthen China's export of electromechanical products production system construction, China's export products toward high-grade, high-end direction.

Second, in recent years, the economic and trade relations between China and Australia have shown close cooperation. In November 2014,Both China and Australia jointly announced the "substantive end since negotiations on free trade agreement" and are intended to be scheduled for the China Australia free trade agreement signed by 2015, and there are broad prospects for economic and trade cooperation between China and Australia, the situation is good. Australia's resources industry and high-tech industry developed, but the processing manufacturing industry is in a small scale; instead China's resources industry and high-tech industry is relatively insufficient, but rich in human resources, processing and manufacturing of large scale, in Asian and international occupies strong competitiveness. China and Australia to promote the complementary development of the two countries, the tight combination of economic and trade cooperation for the two countries to provide an inexhaustible motive force.

Third, We should recognize that the bilateral trade between China and South Korea may encounter resistance, such as South Korea's higher barriers to trade, the trade deficit with China and South Korea seriously, and between China and South Korea trade friction violently; we should also be aware of Sino Australian bilateral trade coincided with the initial stage, the economic structure need further adjustment and reform, making their economies to achieve healthy growth, with a positive attitude to meet new opportunities and challenges. Provides a broader market both South Korea and Australia, for the bilateral economic and trade cooperation, the two sides should in order to enhance the level of bilateral economic and trade cooperation, in order to promote the bilateral economic and trade towards stability, sustained and sound to develop in the direction of health and unremitting efforts, bilateral cooperation rose to a strategic height, in order to achieve a win-win situation.

\section{Acknowledgement}

This article is sponsored by Shandong Provincial Science and Technology Development Planning project(2014GGH213001) " Study on the early warning mechanism of agricultural industry damage of Shandong province from the perspective of global value chain" hosted by Wang Peizhi; Shandong Provincial Natural Science Foundation project(ZR2013GM013) "Research on agricultural products trade's marginal measures and upgrading route of Shandong Province" hosted by Wang Peizhi; Shandong Provincial Academy of Social Sciences project(14AWTJ01-15) " Research on early warning system of financial internationalization development in Shandong Province " hosted by Wang Peizhi; Shandong Education Department's Project (sdyy11201) "Research on Innovation of Bilingual Teaching of Graduates in International Business, Shandong University of Finance and Economics" hosted by Liu Xinying; Project (jy201212 )"Research on Combining Chinese Graduates with Foreign Students in Teaching International Economics and Trade in English" hosted by Liu Xinying; Shandong science and Technology Department Project(2014RKB019A6) "Research on agricultural industry security of Shandong province from the perspective of open market" hosted by Liu Xinying.

\section{References}

[1]monograph: Every Young Min of "seeking to develop China's foreign trade under the FTA framework" [M], Shanghai: Century Publishing, April 2014.

[2] monograph: Reflections on the Issue of the "Political Economy Research China FTA strategy" [M], Beijing: China Economic Publishing House, December 2012.

[3] Wikipedia - China-South Korea relations, China-Australian relations 
[4] Papers: Shou Wei Song, pension Yaqiong, "Sino-Australian bilateral trade relations under the economic globalization of research" [J], APEC, 2005.

[5] Papers: Zhang Jianhong, "China-Australian bilateral trade and trade interests characteristic research" [J], the World Economic Research, 1996.

[6] Papers: Xu Changwen, "the status quo and prospect of bilateral trade and economic development of China-South Korea FTA" [J], International Trade, 2008.

[7] Papers: Kings Hole "structural changes and the development of China-South Korea trade Prospects" [J], Economic Review, 2009. 